2018-12-11

\title{
Geographies of citizenship in higher education: An introduction
}

\section{Cheng, $Y$}

http://hdl.handle.net/10026.1/13170

10.1111/area.12527

Area

Wiley

All content in PEARL is protected by copyright law. Author manuscripts are made available in accordance with publisher policies. Please cite only the published version using the details provided on the item record or document. In the absence of an open licence (e.g. Creative Commons), permissions for further reuse of content should be sought from the publisher or author. 


\section{Geographies of citizenship in higher education: An introduction}

Yi'En Cheng: Yale-NUS College, Singapore, Singapore. yien.cheng@yale-nus.edu.sg

Mark Holton: School of Geography, Earth and Environmental Sciences, University of Plymouth, Plymouth, UK. Mark.holton@plymouth.ac.uk

Accepted - 06 Nov 2018 (embargo until 06 Nov 2020)

How to cite this article: Cheng, Y., and Holton, M. (2018). Geographies of citizenship in higher education: An introduction. Area: 1-5. https://doi.org/10.1111/area.12527

This special section explores multiple ways of thinking about citizenship as informed by higher education students' experiences. The papers collectively examine universities as a locus of citizenship production and consumption among students, but also highlight the role of young people in enacting alternative expressions of citizenship. All the papers locate experiences of higher education within their national contexts operating within broader geopolitical and geo-economic practices, even as they take into consideration "postnational" forms of citizenship construct as well as a growing range of educational institutions and actors occupying subnational terrains that mediate citizenship values, ideals and norms. Drawing on these insights, we point towards three promising avenues for further research in the geographies of citizenship in higher education, while maintaining that this an area of studies that requires a plurality of perspectives.

KEYWORDS citizenship, higher education, student geographies, universities, young people

\section{INTRODUCTION}

The intersection between citizenship and higher education occupies an important place in social science inquiry concerned with state-society relations, the social reproduction of youth inequalities, the cultural production of identities and the role of universities in fostering values within communities (Brooks \& Holford, 2009; Rao et al., 2016). Indeed, it is at the heart of universities and colleges that many of these issues become increasingly complex, given rapid changes across political-economic regimes, institutional policies and socio-cultural lifestyles and practices. Higher education is a vital spatio-temporal terrain in which contemporary youths face confounding challenges in terms of navigating education to work transitions, cultivating professional and adult identities, as well as learning to fulfil a range of obligations and responsibilities tied to post-study lives (Allen et al., 2013; Bregnbæk, 2016; Holloway et al., 2012; Roberts, 2013). The restructuring of 
higher education in many parts of the world through policy changes is leading to rising tuition fees, the expansion of student mobility programmes, curricular and extra-curricular revamps and so on, further complicating these experiences (Holdsworth, 2017; Urciuoli, 2018). Crucially though, university campuses are also forward-looking spaces in that they serve as "micro-publics" in which young people can learn from and negotiate diversity (Harris, 2012), or provide resources for political or activist mobilisation that enable political work to be done (Crossley \& Ibrahim, 2012). It is here that we consider citizenship - whether it is constitutional-legal status tied to certain rights and responsibilities or practised by people as they navigate obstacles to carve out spaces and communities of belonging or even as embodied, sensuous and felt within the psychic and emotional realms - as a productive lens to help us make sense of these diverse and shifting relationships between higher education and young people as they become increasingly defined through dominant constructs such as "student citizens," "graduate citizens" or "worker citizens."

Geographers among others have contributed to these strands of work by placing internationalisation and transnationalisation of education; and the rising importance of alternative spaces of learning. These writings explore issues from globalised networks of students moving around the world to intra/rural-urban educational migration (Beech, 2014; Prazeres, 2013; Smith, 2017), through to the neoliberalisation of higher education policies that have heavily marketised (transnational) degree programmes (Cheng, 2014; Davidson, 2008; Waters \& Leung, 2016); from students negotiating sense of belonging during term-time accommodation (Holton, 2015) to their active mobilisations through organisations and unions (Brooks et al., 2015); from the mounting pressure on students to search for and acquire "useful" cultural and embodied capitals, such as critical thinking, emotional intelligence and global competencies (Cheng, 2016a, 2016b; Hall, 2009; Yoon, 2014), to the ways in which students' identities are negotiated, accepted or rejected on campuses (Andersson et al., 2012; Hopkins, 2011). At the same time, class, gender, race/ethnicity and other social differences continue to act as prisms through which citizenship inequalities and subjectivities are (re)produced, even though these can also occur alongside hopeful practices of love, care, solidarity and anti-injustice (Cheng, 2016a, 2016b). Running through these discussions have been calls for an "outward looking" and "de-centred" geography of education (Holloway et al., 2010; Holton \& Riley, 2016; Thiem, 2008) that reaches out to wider conceptual debates within Geography and beyond. This special section is comprised of five papers that are interested in multiple ways of thinking about citizenship as informed by university students' experiences during and beyond term-time, their mobilities across various scales and borders, and their engagement with explicit and implicit forms of politics within and outside the campus space. The papers are concerned with a younger segment of the university student population who are the core target group of many higher education markets and global and 
national citizenship-making projects. But we also acknowledge the presence of older students pursuing undergraduate, postgraduate and other forms of continuing education programmes that have emerged under a global interest in lifelong learning (Field, 2006). Focusing on young undergraduate students, the papers critically unpack the ways in which dominant understandings of the "student" and "student experience" in higher education as singular and relational are assembled through representations, discourses and practices of citizenship within particular political-economic and socio-cultural regimes, while also incorporating into their analyses students' responses to the burdens placed on them in terms of peer, institutional and policy pressures and the extent to which this might act as potential catalysts for change. Although the authors demonstrate how national and regional processes around state education policies, institutional aspirations and cultures of youth are highly varied across contexts within North America, Europe, South Africa and East Asia, they also collectively point to a global neoliberalisation of university structures that bring about pernicious impacts on students' lives alongside opportunities for students to forge alliances and rethink their identities as higher education students. Taken together, the papers that form this special section assert the fundamental importance of citizenship as simultaneously bounded but also performative, and relationally produced rather than being a product of individual achievement. Such an approach resonates with and reflects the theoretical richness in geographical research on citizenship and its emphasis on grounding citizenship experiences in the actual sites and spaces where their meanings are produced (Desforges et al., 2005; Dickinson et al., 2008; Staeheli et al., 2012).

As demonstrated by these authors, universities serve as a locus of citizenship production and consumption among students. Cheng's (2018) paper underscores the emergence of liberal arts higher education in East Asia that places a strong emphasis on the cultivation of student citizenship and moral habits. Through an analysis of institutional messages across three self-identified liberal arts colleges/universities, he contends a model of the "liberal arts educated citizen" that is globally oriented, socially responsible and ethical is emerging in the region. He also argues that "students play a crucial role in experimenting and testing the boundaries of citizenship imagined by the institution" (p. 7), which reflects the ambiguities of citizenship subjectification, thereby revealing the openness of any citizenship-making project promulgated by higher education. Webb's (2018) paper demonstrates how post-apartheid educational reform to abolish race-based admission policies represented the South African Government's efforts to promote collective intergenerational mobility through higher education. Yet, while this "presented an opportunity for reimagining social citizenship in the new South Africa" (p. 2), the neoliberal-style policies also saw revealed competition and rising fees among universities that resulted in student loans and debts. Webb (2018) argues that 
while historical inequities are partially addressed under this reform, new class divisions and youth vulnerabilities are generated.

The papers by Dimpfl and Smith (2018) and Sertanya (2018) examine "global education" programmes in US higher education that are designed to cultivate students into cosmopolitan and globally oriented citizen-subjects. Dimpfl and Smith draw on the case of a single US university to reveal the manner in which "mechanisms by which especially neoliberal cosmopolitanisms require an intentional and narrow rendering of what and who counts in the production of campus life" $(2018$, p. 1). They demonstrate that even as the university prioritises diversity and global-ness in its bid to promote global citizenship, critical issues surrounding institutional racism and low-wage worker precarity continue to be ignored by the institution. In extrapolating their analysis out to wider higher education issues, their paper draws attention to an irony about the university's global citizenship programme: a preoccupation with an unequal world "out there" may come at the cost of side-stepping systemic inequalities occurring in institutions' own backyards. Sertanya (2018) provides an altogether different strand of critique about global citizenship that emphasises tendencies to be associated with individualistic capital accumulation. Using interview narratives from low-income college students who undertook study abroad programmes as part of their university experience, Sertanya (2018) underlines the importance of locating instances of relational care, solidarity and affection because they begin to piece together a different picture of global citizenship among students. She maintains that a care-based interpretation of citizenship is crucial for understanding the multiple ways young people experience global encounters, even if they exist alongside racial and class dynamics, and that these caring practices and subjectivities constitute a key expression of youth political agency.

Lupatini's (2018) paper flips the question of citizenship production back onto ourselves as scholars and educators, asking what kind of pedagogical tools we can use to cultivate students into critically informed citizens of society. As an educator at a teacher-training institute, Lupatini (2018) stresses that educating young people is a critical project that involves "fostering [within them] the acquisition of the instruments required in order to live citizenship dynamically," and that ensures young people understand their societal roles as spatial actors. Focusing on the use of controversies around public space, his paper emphasises the value of incorporating place-based educational tasks that go beyond simply engaging students, encouraging them to confront controversial topics that create opportunities for young people to (re)evaluate their role and status as citizens. As such, Lupatini (2018) argues that the focus on controversy appears to activate more dynamic, contrasting and 
contested views and opinions on citizenship that can encourage learners to challenge their position as "youths-as- citizens" in society.

Collectively, these papers hint at alternative expressions of citizenship that shift beyond their respective study contexts, to highlight the role of young people in enacting them. Webb's (2018) and Dimpfl and Smith's (2018) papers reveal the central role of student resistance in pressurising for institutional change. Here, social actions not only oppose the dominant and narrowly elitist models of citizenship, but also expose the hidden injuries that such models tend to obscure, and in a manner that exceeds the students' own particular interests to include those of workers such as cleaners and frontline housekeepers. Interestingly, Sertanya's (2018) argument that students are capable of practising relational care found resonance in these two case studies, especially through young people's radical sensing of social justice, while she makes clear in her own study that caring citizenship offers an alternative glimpse into student engagement with global mobility. Cheng's (2018) paper highlights the potential for liberal arts education to represent a space with bounded potential for students to experiment with political ideas and practices that would otherwise be impermissible outside campus. Lupatini's (2018) paper suggests, along a similar line, that the classroom (or field location) serves as an important pedagogical site for students to encounter controversies, develop critical spatial awareness and become reflexive urban citizens. Perhaps what all the authors implicitly point towards is an urgent need for higher education actors, including policy-makers, administrators and educators, to re-imagine universities and colleges based on morethan-neoliberal forms of citizenship that rest on orientations towards justice, ethical care and a commitment to forge spaces for cross-class and cross-cultural affinities to flourish.

The geographical diversity of work included in this collection emphasises the centrality of national contexts operating within broader geopolitical and geo-economic practices in framing contemporary higher education, even as the role of higher education has shifted from one of producing national citizens to that of making "postnational" globally savvy citizens of the world (Mitchell, 2017). It also showcases the sub-national terrains occupied by a growing range of educational institutions and actors in mediating the formulation and maintenance of citizenship values, ideals and norms, constantly reworking them at different spaces and times through both individual and collective means. It is within this diversifying, cross-scalar and multi-sited web of connections that we point towards three promising avenues for further research in the geographies of citizenship in higher education, among other agendas. First, we suggest greater attention to the political economy of higher education citizenship that examines how higher educational institutions have become linked to wider (youth) citizenship projects led by diverse actors other than the state government including, 
for instance, private enterprises and intermediaries, non-profit and non-governmental organisations, and international bodies like the World Bank and UNESCO (Sukarieh \& Tannock, 2015). Second, we need more critical analyses of the contradictions that percolate young people's citizenship performances in and through higher education. Although universities and colleges provide the spaces, times and resources for students to develop multicultural, cosmopolitan and political citizenships, these ostensibly positive enactments may exist alongside or even mask gendered, racialised and classed power structures operating stealthily within other sites tied to the lives of students and those actors who co-produce the higher education experience (see also Dimpfl, 2018), such that there is considerable ambiguity to how citizenship in higher education is being produced and consumed. Third, the omitted discussion of the relationship between citizenship and older students in higher education within this collection signals the need for more scholarly attention on this topic. Research along this line may become even more important as student bodies at universities become increasingly diverse in terms of age. This is particularly so for places where a new market for adult learners has emerged against the backdrop of increasing emphasis on lifelong learning and even more strikingly in countries where shrinking youth population is challenging student enrolment at universities (Klemencic \& Fried, 2007).

Through this non-exhaustive collection of papers, we have provided a glimpse into the contemporary studies that energise geographical research on citizenship production and consumption among young students in higher education. We maintain that a plurality of perspectives is needed to decipher and unpack "citizenship" as it relates both to higher education and to young people. We also hope that it serves to spur further research into the question of citizenship in higher education, and in ways that are connected to broader debates about economic restructuring, social reproduction, cultural identities, political life, and life course and age.

ACKNOWLEDGEMENTS The papers included in this special section were originally presented at the AAG Annual Conference in 2017, Boston. We are extremely grateful to all participants of the session, our contributing authors, the anonymous reviewers, and the editor and managing editor for assisting us in putting together this collection.

\section{REFERENCES}

Allen, K., Quinn, J., Hollingworth, S., \& Rose, A. (2013). Becoming employable students and 'ideal' creative workers: Exclusion and inequality in higher education work placements. British Journal of Sociology of Education, 34, 431-452. https://doi.org/10.1080/01425692.2012.714249 
Andersson, J., Sadgrove, J., \& Valentine, G. (2012). Consuming campus: Geographies of encounter at a British university. Social \& Cultural Geography, 13, 501-515.

https://doi.org/10.1080/14649365.2012.700725

Beech, S. E. (2014). Why place matters: Imaginative geography and international student mobility. Area, 46, 170-177. https://doi.org/10.1111/area.12096

Bregnbæk, S. (2016). The Chinese race to the bottom: The precarious lives of unemployed university graduates in Beijing's 'Ant Tribe'. Critical Sociology, 42, 989-1002.

https://doi.org/10.1177/0896920515604476

Brooks, R., Byford, K., \& Sela, K. (2015). Students' unions, consumerism and the neo-liberal university. British Journal of Sociology of Education, 37, 1211-1228.

https://doi.org/10.1080/01425692.2015.1042150

Brooks, R., \& Holford, J. A. K. (2009). Citizenship, learning and education: Themes and issues. Citizenship Studies, 13, 85-103. https://doi.org/10.1080/13621020902749027

Cheng, Y. (2014). Biopolitical geographies of student life: Private higher education and citizenship life-making in Singapore. Annals of the Association of American Geographers, 105, 1078-1093. https://doi.org/10.1080/00045608.2015.1059179

Cheng, Y. (2016a). Learning in neoliberal times: Private degree students and the politics of value coding in Singapore. Environment and Planning A, 48, 292-308.

https://doi.org/10.1177/0308518X15613355

Cheng, Y. (2016b). Critical geographies of education beyond "value": Moral sentiments, caring, and a politics for acting differently. Antipode, 48, 919-936. https://doi.org/10.1111/anti.12232

Cheng, Y. (2018). Liberal arts educated citizen: Experimentation, subjectification and ambiguous contours of youth citizenship. Area. Advance online publication. https://doi.org/10.1111/area.12440

Crossley, N., \& Ibrahim, J. (2012). Critical mass, social networks and collective action: Exploring student political worlds. Sociology, 46, 596-612. https://doi.org/10.1177/0038038511425560 Davidson, E. (2008). Marketing the self: The politics of aspiration among middle-class Silicon Valley youth. Environment and Planning A, 40, 2814-2830. https://doi.org/10.1068/a4037 
Desforges, L., Jones, R., \& Woods, M. (2005). New geographies of citizenship. Citizenship Studies, 9, 439-451. https://doi.org/10.1080/13621020500301213

Dickinson, J., Andrucki, M. J., Rawlins, E., \& Cook, V. (2008). Introduction: Geographies of everyday citizenship. ACME: An International E- Journal for Critical Geographies, 7, 100-112.

Dimpfl, M. (2018). Micro(bial) management: Everyday cleanliness and the divisive power of hygienic worries. Cultural Geographies, 25, 201- 216. https://doi.org/10.1177/1474474017724478

Dimpfl, M., \& Smith, S. (2018). Cosmopolitan sidestep: University life, intimate geopolitics and the hidden costs of "Global" citizenship. Area. Advance online publication.

https://doi.org/10.1111/area.12497

Field, J. (2006). Lifelong learning and the new educational order. London, UK: Trentham Books.

Hall, S. (2009). Ecologies of business education and the geographies of knowledge. Progress in Human Geography, 33, 599-618. https://doi.org/ 10.1177/0309132509103154

Harris, A. (2012). Young people and everyday multiculturalism. New York, NY: Routledge.

Holdsworth, C. (2017). The cult of experience: Standing out from the crowd in an era of austerity. Area, 49, 296-302. https://doi.org/10.1111/area.12201

Holloway, S. L., Hubbard, P., Jons, H., \& Pimlott-Wilson, H. (2010). Geographies of education and the significance of children, youth and families. Progress in Human Geography, 34, 583-600.

https://doi.org/10.1177/0309132510362601

Holloway, S. L., O'Hara, S. L., \& Pimlott-Wilson, H. (2012). Educational mobility and the gendered geography of cultural capital: The case of international student flows between Central Asia and the UK. Environment and Planning A, 44, 2278-2294. https://doi.org/10.1068/a44655

Holton, M. (2015). Adapting relationships with place: Investigating the evolving place attachment and 'sense of place' of UK higher education students during a period of intense transition.

Geoforum, 59, 21-29. https://doi.org/10.1016/j.geoforum.2014.11.017

Holton, M., \& Riley, M. (2016). Student geographies and homemaking: Personal belonging(s) and identities. Social \& Cultural Geography, 17, 623-645.

https://doi.org/10.1080/14649365.2015.1126626 
Hopkins, P. (2011). Towards critical geographies of the university campus: Understanding the contested experiences of Muslim students. Transactions of the Institute of British Geographers, 36, 157-169. https://doi.org/10.1111/i.1475-5661.2010.00407.x

Klemencic, M., \& Fried, J. (2007). Demographic challenges and the future of the higher education. International Higher Education, 47, 12-14. https://doi.org/10.6017/ihe.2007.47.7956

Lupatini, M. (2018). Controversies on public space management projects in Geography teaching and education to educate pupils as dynamic citizen. Area. Advance online publication.

https://doi.org/10.1111/area.12523

Mitchell, K. (2017). Making workers: Radical geographies of education. London, UK: Pluto Press.

Prazeres, L. (2013). International and intra-national student mobility: Trends, motivations and identity. Geography Compass, 7, 804-820. https://doi.org/10.1111/gec3.12080

Rao, N., Janmaat, G., \& McCowan, T. (2016). Higher education, learning and citizenship. Compare: A Journal of Comparative and International Education, 46, 1-4.

https://doi.org/10.1080/03057925.2016.1110355

Roberts, K. (2013). Education to work transitions: How the old middle went missing and why the new middle remains elusive. Sociological Research Online, 18, 1-11. https://doi.org/10.5153/sro.2650

Sertanya, R. (2018). Going global: Internationally mobile young people as caring citizens in higher education. Area. Advance online publication. https://doi.org/10.1111/area.12503

Smith, S. (2017). Politics, pleasure, and difference in the intimate city: Himalayan students remake the future. Cultural Geographies, 24, 573-588. https://doi.org/10.1177/1474474017719906

Staeheli, L., Ehrkamp, P., Leitner, H., \& Nagel, C. R. (2012). Dreaming the ordinary: Daily life and the complex geographies of citizenship. Progress in Human Geography, 36, 628-644.

https://doi.org/10.1177/0309132511435001

Sukarieh, M., \& Tannock, S. (2015). Youth rising? The politics of youth in the global economy. London, UK: Routledge.

Thiem, C. H. (2008). Thinking through education: The geographies of contemporary educational restructuring. Progress in Human Geography, 33, 154-173. 
Urciuoli, B. (2018). The experience of neoliberal education. New York, NY: Berghahn.

Waters, J. L., \& Leung, M. W. H. (2016). Domesticating transnational education: Discourses of social value, self-worth and the institutionalisation of failure in 'meritocratic' Hong Kong. Transactions of the Institute of British Geographers, 42, 233-245. https://doi.org/10.1111/tran. 12163

Webb, C. (2018). Asinamali: Aspiration, debt and citizenship in South Africa's \#FeesMustFall protests. Area. Advance online publication. https://doi.org/10.1111/area.12489

Yoon, K. (2014). Transnational youth mobility in the neoliberal economy of experience. Journal of Youth Studies, 17, 1014-1028. https://doi.org/10.1080/13676261.2013.878791 